\title{
Pilocytic astrocytoma with anaplasia arising from the optic chiasm in a very elderly patient
}

\section{Figure $\quad$ MRI and pathology}

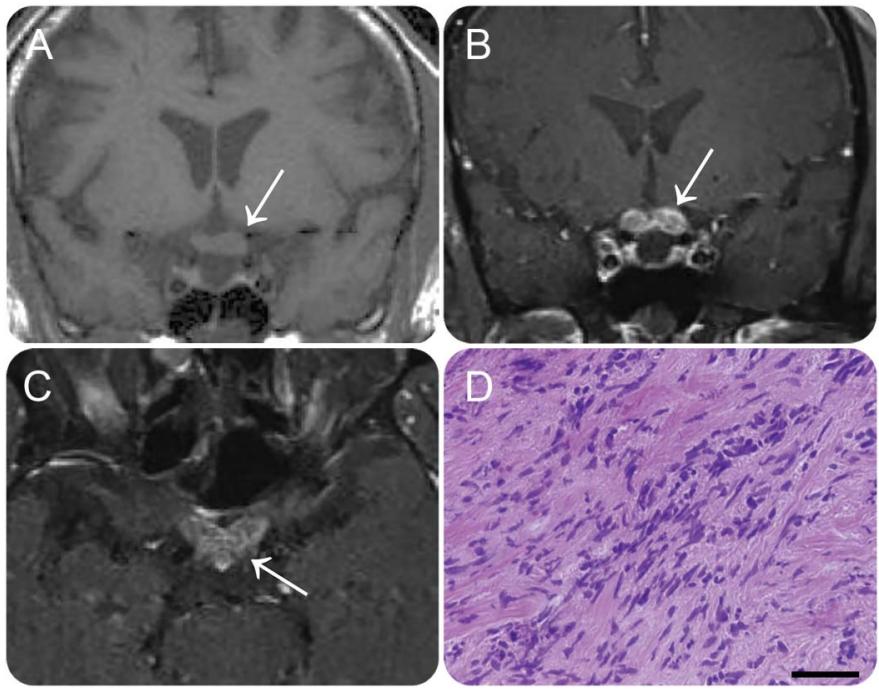

T1-weighted images show moderately enlarged optic chiasm ( $A$, arrow) with contrast enhancement (B, C, arrows). Biopsy (D) reveals elongated cells with anaplasia, occasional Rosenthal fibers, microvascular proliferation, and necrotic foci. The BRAF V600E mutation was not detected by immunohistochemistry (Spring Bioscience, Pleasanton, CA; monoclonal antibody). Bar $=20 \mu \mathrm{m}$.

An 81-year-old man presented with a 3-week history of impaired visual acuity (100/200 right eye, 2/200 left eye). He had a central scotoma (left eye) and bitemporal hemianopsia, with no abnormality in the optic discs. Cranial MRI suggested a tumor predominantly located at the optic chiasm and extending to the optic nerves, identified pathologically as pilocytic astrocytoma with anaplasia (PAA) (figure). He received temozolomide (for 14 months) and irradiation, but the tumor eventually extended to the hypothalamus. This unusual case of histologically proven PAA demonstrates an origin from the optic chiasm, ${ }^{1}$ which is extremely rare in the elderly. ${ }^{2}$

Shintaro Hayashi, MD, PhD, Norihiko Akao, MD, Yoichi Nakazato, MD, PhD, Koichi Okamoto, MD, PhD

From the Department of Neurology (S.H.), Gunma Rehabilitation Hospital, Agatsuma; Department of Neurology (S.H.), Gunma University Graduate School of Medicine, Maebashi; Department of Neurosurgery (N.A.), Numata Neurosurgery and Heart Disease Hospital; Department of Pathology (Y.N.), Hidaka Hospital, Takasaki; and Department of Neurology (K.O.), Geriatrics Research Institute and Hospital, Maebashi, Japan.

Author contributions: S. Hayashi: drafting/revising the manuscript, acquisition of data, data analysis or interpretation of data. N. Akao: drafting/revising the manuscript, acquisition of data, data analysis or interpretation of data. Y. Nakazato: pathologic study, drafting/ revising the manuscript. K. Okamoto: drafting/revising the manuscript, acquisition of data, data analysis or interpretation of data, study supervision.

Study funding: Supported by a Grant-in-Aid for Scientific Research (No. 16K09721) from the Ministry of Education, Science, Sports, Culture and Technology of Japan to S. Hayashi.

Disclosure: The authors report no disclosures relevant to the manuscript. Go to Neurology.org for full disclosures.

Correspondence to Dr. Hayashi: shintaro@neuro.med.kyushu-u.ac.jp

1. Fiechter M, Hewer E, Urspeter K, et al. Adult anaplastic pilocytic astrocytoma-a diagnostic challenge? A case series and literature review. Clin Neurol Neurosurg 2016;147:98-104.

2. Azad A, Deb S, Cher L. Primary anaplastic pilocytic astrocytoma. J Clin Neurosci 2009;16:1704-1706. 


\section{Neurology}

\section{Pilocytic astrocytoma with anaplasia arising from the optic chiasm in a very elderly patient}

Shintaro Hayashi, Norihiko Akao, Yoichi Nakazato, et al. Neurology 2017;89;1840

DOI 10.1212/WNL.0000000000004575

This information is current as of October 23, 2017

\section{Updated Information \& Services}

\section{References}

Citations

Subspecialty Collections

Permissions \& Licensing

Reprints including high resolution figures, can be found at: http://n.neurology.org/content/89/17/1840.full

This article cites 2 articles, 0 of which you can access for free at: http://n.neurology.org/content/89/17/1840.full\#ref-list-1

This article has been cited by 2 HighWire-hosted articles: http://n.neurology.org/content/89/17/1840.full\#\#otherarticles

This article, along with others on similar topics, appears in the following collection(s):

\section{All Neuro-ophthalmology}

http://n.neurology.org/cgi/collection/all_neuroophthalmology

MRI

http://n.neurology.org/cgi/collection/mri

Optic nerve

http://n.neurology.org/cgi/collection/optic_nerve

Primary brain tumor

http://n.neurology.org/cgi/collection/primary_brain_tumor

\section{Visual loss}

http://n.neurology.org/cgi/collection/visual_loss

Information about reproducing this article in parts (figures,tables) or in its entirety can be found online at:

http://www.neurology.org/about/about_the_journal\#permissions

Information about ordering reprints can be found online:

http://n.neurology.org/subscribers/advertise

Neurology ${ }^{\circledR}$ is the official journal of the American Academy of Neurology. Published continuously since 1951, it is now a weekly with 48 issues per year. Copyright @ 2017 American Academy of Neurology. All rights reserved. Print ISSN: 0028-3878. Online ISSN: 1526-632X.

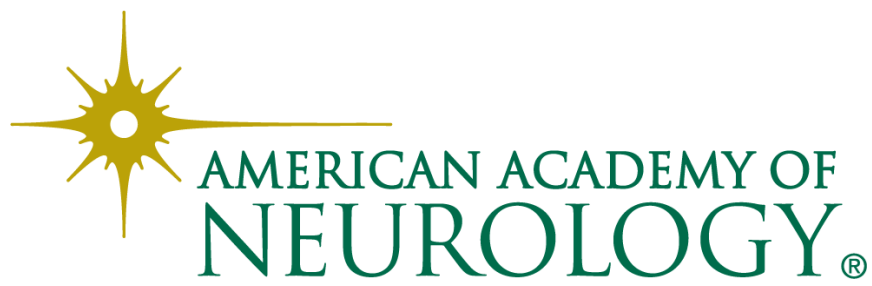

